\title{
Novel Ag/Kaolin Nanocomposite as Adsorbent for Removal of Acid Cyanine 5R from Aqueous Solution
}

\author{
Saeedeh Hashemian and Mohammad Reza Shahedi \\ Chemistry Department, Islamic Azad University, Yazd Brunch, Yazd, Iran \\ Correspondence should be addressed to Saeedeh Hashemian; sa_hashemian@yahoo.com
}

Received 27 May 2013; Revised 21 September 2013; Accepted 25 September 2013

Academic Editor: Saima Q. Memon

Copyright ( 2013 S. Hashemian and M. Reza Shahedi. This is an open access article distributed under the Creative Commons Attribution License, which permits unrestricted use, distribution, and reproduction in any medium, provided the original work is properly cited.

\begin{abstract}
$\mathrm{Ag} / \mathrm{kaolin}$ nanocomposite was prepared by reduction of $\mathrm{Ag}^{+}$ion with ethanol at alkaline condition on kaolin surface. Nanocomposite was characterized by FTIR, XRD, TEM, and BET methods. Results showed the Ag/kaolin composite has particle size $50 \mathrm{~nm}$. The surface area was increased from kaolin to $\mathrm{Ag} / \mathrm{kaolin}$ from 1.0215 to $7.409 \mathrm{~m}^{2} \mathrm{~g}^{-1}$, respectively. Ag/kaolin nanocomposite was used for adsorption of acid cyanine 5R (AC5R) from aqueous solution. The effect of parameters such as contact time, $\mathrm{pH}$, and mass of nano composite has been investigated. The maximum percentage of adsorption of AC5R was found at $\mathrm{pH} 3$ and contact time of $60 \mathrm{~min}$. The higher percentage removal of AC5R by Ag/kaolin than kaolin can be attributed to catalytic activity of Ag on the surface of kaolin. The experimental data was fitted by pseudo-second-order kinetic model. The adsorption isotherm data could be well interpreted by Langmuir isotherm model. From the results of thermodynamic study, the adsorption process of AC5R onto Ag/kaolin nanocomposite was spontaneous and endothermic process. The process is clean and safe for purifying of water pollution.
\end{abstract}

\section{Introduction}

The effluent from many chemical and textile industries is major source of water pollution. They contain organic compounds and dyes. Many colors and dyes are toxic and carcinogenic. Large volumes of colored aqueous effluents are discharged to environment by the various divisions, such as textiles and painting. Numbers of techniques are available for the treatment of wastewater such as photocatalytic degradation, coagulation, electrochemical technique, and adsorption [1-7]. Adsorption has proven usual process, more efficient, and economically feasible for the removal of variety of contaminants [8-12]. Adsorption of some dyes and organic compounds with different sorbents was investigated [1315]. Adsorption of cyanine dyes to solid surfaces has evoked interest from both a basic and technological point of view. The adsorption behavior of some cyanine dyes has been studied [16]. Adsorption on the surface of semiconductor powders such as $\mathrm{ZnO}, \mathrm{TiO}_{2}, \mathrm{AgCl}$ and on silica, are some of the interesting applications of the dyes adsorbed on a solid surface [17].
Mineral clays are widely applied in ceramics, paper filling and coating, catalysts, adsorbents, and nanocomposites [1824]. Mineral clays have been extensively studied for potential applications as environmental remediation agents to remove heavy metals and organic contaminants from water. The montmorillonite and kaolin group clays were used as adsorbent $[25,26]$. Kaolin is one of the most common clay minerals found on the surface of the earth. The general structure of the kaolinite group is composed of silicate sheets $\left(\mathrm{Si}_{2} \mathrm{O}_{5}\right)$ banded to aluminum oxide/hydroxide layers $\left(\mathrm{Al}_{2}(\mathrm{OH})_{4}\right)$. Ag is an important inorganic material that has wide applications perspective in catalysis [27-29]. Cyanine dyes are widely used as fluorescent probes for visualization of nucleic acids in electrophoretic gels. Unfortunately, some of these dyes are known to have mutagenic and carcinogenic activity. Cyanine dyes beside the ability to intercalate into DNA molecule also appeared to have complex binding modes, obviously involving interactions with sites in the major or minor grooves and/or with the phosphate backbone of DNA molecules. Such properties could point to the possibility that the abovementioned cyanine dyes are mutagenic [30]. 


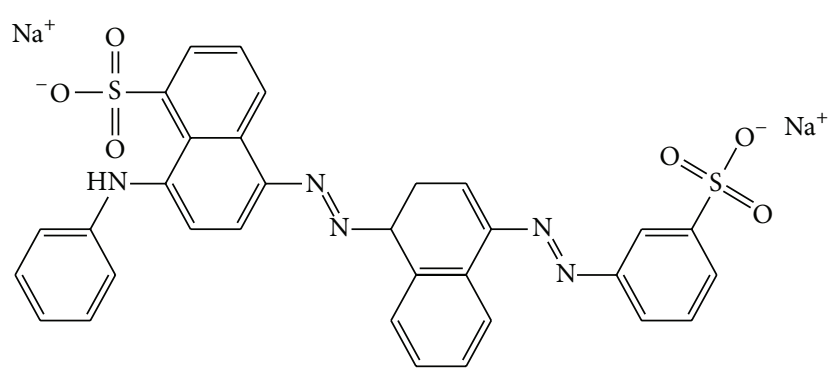

FIGURE 1: Chemical structure of acid cyanine 5R.

In this work, we used the adsorption layer on the surface of kaolin as a reactor to prepare Ag/Kaolin nanocomposite material. The adsorption behavior of acid cyanine $5 \mathrm{R}$ onto Ag/Kaolin was studied.

\section{Experimental}

2.1. Reagent and Apparatus. Silver nitrate, ethyl alcohol, hydrochloride acid, and sodium hydroxide were purchased from Merck. All of the reagents were analytical reagent grade. Acid cyanine 5R dye (sodium 8-(phenylamino)-5-((E)-(5((E)-(3-sulfonatophenyl)diazenyl)naphthalen-1-yl)diazenyl) naphthalene-1-sulfonate) was purchased from $\mathrm{BDH}$ and was used as received, without purification $\left(\mathrm{C}_{32} \mathrm{H}_{21} \mathrm{~N}_{5} \mathrm{Na}_{2} \mathrm{O}_{6} \mathrm{~S}_{2}=\right.$ 682). The chemical structure of cyanine dye is shown in Figure 1. Kaolin was obtained from laabe yazd co of Iran from ceramic industry.

IR measurements were performed by FT-IR tensor-27 of Burker Co., using the $\mathrm{KBr}$ pellet. UV-Vis spectrophotometer 160 A Shimadzu was used for determination of concentration of AC5R. All pH measurements were carried out with an ISTEK-720P pH meter. The powder X-ray diffraction studies were made on Philips PW3719 X-ray diffractometer by using $\mathrm{Cu}-\mathrm{K}_{\alpha}$ radiation of wave length $1.54060 \AA$. The morphology of the nanocomposite was characterized by transmission electron microscopy (TEM Philips-CM). The nitrogen adsorption/desorption isotherms were measured by Quanta chrome, Autosorb-1.

2.2. Preparation of Ag/kaolin Nanocomposite. The kaolin was crushed and passed through a 100-mesh sieve and baked at $150^{\circ} \mathrm{C} .2 \mathrm{~g}$ kaolin and $200 \mathrm{~mL}$ absolute ethyl alcohol were added and well mixed in triflask. After that kaolin was well dispersion and water and $\mathrm{NaOH}(5 \%)$ with constant ratio 1:1 were added into the reaction system and adsorbed under stirred condition. After that, $30 \mathrm{~mL}$ of $\mathrm{AgNO}_{3} 7.6 \mathrm{~g} \mathrm{~L}^{-1}$ in ethyl alcohol was added at a rate of $0.5 \mathrm{~mL} / \mathrm{min}$ and reacts with $\mathrm{NaOH}$ and reduced by ethanol [31].

\section{Results and Discussion}

3.1. Characterization of Ag/kaolin. FTIR of kaolin and Ag/kaolin are given in Figure 2. The bands $3620-3760 \mathrm{~cm}^{-1}$ correspond to stretching vibration of $\mathrm{OH}$ groups attached to octahedral layer of kaolin. The $\mathrm{Si}-\mathrm{O}$ stretching band in the $1119 \mathrm{~cm}^{-1}$, and the $\mathrm{Si}-\mathrm{O}-\mathrm{Si}$ asymmetric stretching band in

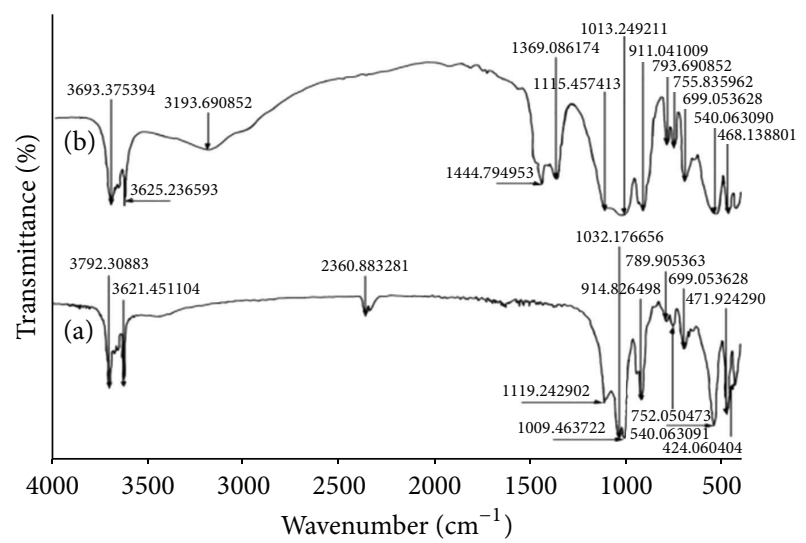

Figure 2: FTIR spectra of (a) kaolin and (b) Ag/kaolin.

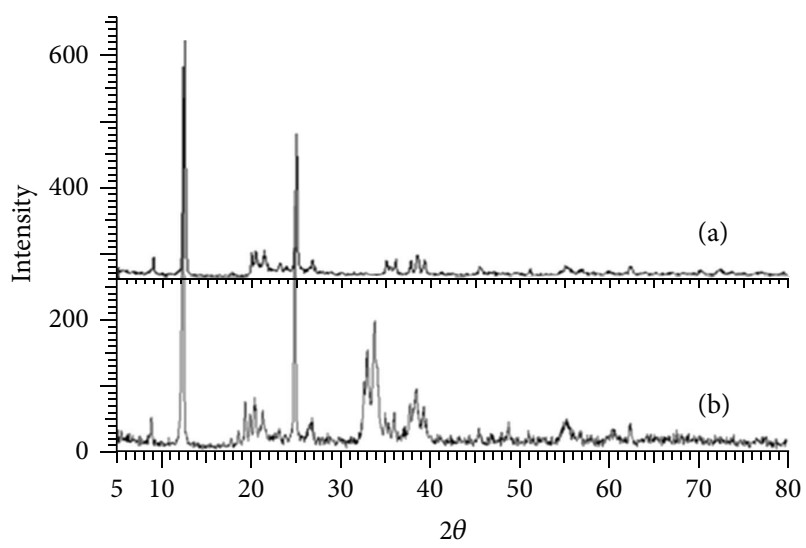

FIGURE 3: XRD pattern of (a) kaolin and (b) Ag/kaolin.

the $1032 \mathrm{~cm}^{-1}$, the $\mathrm{Si}-\mathrm{O}-\mathrm{Al}$ bending band in the $540 \mathrm{~cm}^{-1}$ are clearly seen. The broad bond around $3250 \mathrm{~cm}^{-1}$ and bonds 1448 and $1369 \mathrm{~cm}^{-1}$ (Figure 2(b)) have shown the characteristic absorption bands of nitrate from $\mathrm{AgNO}_{3}$ onto kaolin. The bond $468 \mathrm{~cm}^{-1}$ is attributed to the presence of $\mathrm{Ag}$ onto kaolin [32].

The X-ray diffraction pattern of kaolin and Ag/kaolin is given in Figures 3(a) and 3(b), respectively. The X-ray diffraction pattern of kaolin indicates the wide peaks attributed on crystalline quartz $\left(2 \theta=12,20,22,25\right.$, and $\left.56^{\circ}\right)$. From X-ray diffraction pattern of $\mathrm{Ag} / \mathrm{kaolin}$, the peaks of quartz were observed and peaks at $2 \theta=33,34$ and $2 \theta=38,39$ were attributed to the Ag on the surface of kaolin. These reflections indicate the presence of $\mathrm{Ag}$ from $\mathrm{AgNO}_{3}$ on the surface of kaolin.

The pattern of the sample matched well with the standard patterns of silver (JCPDS file no. 04-0783). All of the peaks of the patterns of the samples can be readily indexed to face centered-cubic silver (JCPDS file no. 04-0783), where the diffraction peaks at $2 \theta$ values of $34,38^{\circ}$ can be ascribed to the reflection of (111) and diffraction peaks at $2 \theta$ values of 48 and $64.4^{\circ}$ can be ascribed to the reflection of (220) planes of the face-centered-cubic silver, respectively. These reflections 


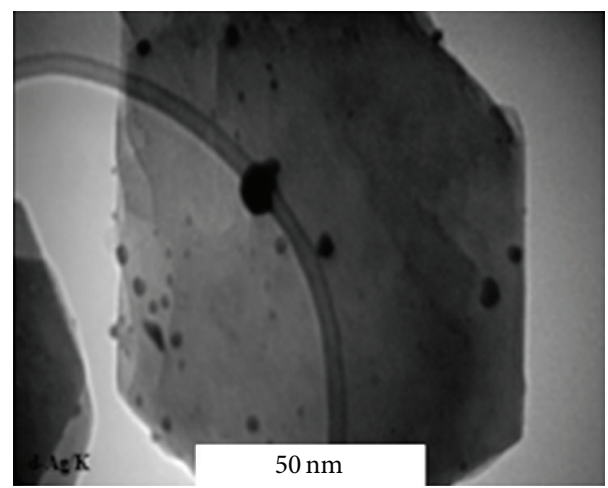

FIgURE 4: TEM image of $\mathrm{Ag} / \mathrm{kaolin}$ nanocomposite.

TABLE 1: List of the BET specific surface parameters of kaolin and $\mathrm{Ag} /$ kaolin nano composite.

\begin{tabular}{lccc}
\hline Adsorbent & \multicolumn{3}{c}{ Texture parameters $\left(\mathrm{N}_{2}\right.$ adsorption) } \\
& $\begin{array}{c}\text { Surface area } \\
\left(\mathrm{m}^{2} \mathrm{~g}^{-1}\right)^{\mathrm{a}}\end{array}$ & $\begin{array}{c}\text { Pore volume } \\
\left(\mathrm{cm}^{3} \mathrm{~g}^{-1}\right)^{\mathrm{a}}\end{array}$ & $\begin{array}{c}\text { Pore diameter } \\
(\mathrm{nm})\end{array}$ \\
\hline Kaolin & 1.0215 & 0.1064 & 41.652 \\
Ag/kaolin & 7.409 & 1.7023 & 54.709 \\
\hline
\end{tabular}

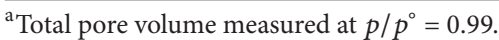

indicate the presence of $\mathrm{Ag}$ from $\mathrm{AgNO}_{3}$ on the surface of kaolin (Figure 3(b)).

The average crystalline size of the $\mathrm{Ag} / \mathrm{kaolin}$ nanoparticles was determined by the Scherrer equation:

$$
d=\frac{k \lambda}{\beta \cdot \cos \theta},
$$

where $d$ is the average size of the particles, $k=0.94, \lambda$ is wavelength of X-ray radiation from $\mathrm{Cu}-\mathrm{K}_{a}(\lambda=1.54 \mathrm{~nm})$, $\beta$ is the full height at half maximum of the diffraction peak, and $\theta$ is the angel of diffraction. The average crystalline size of Ag/kaolin nanoparticles was $45-70 \mathrm{~nm}$. This confirmed the particle size of Ag/kaolin was obtained from TEM image.

TEM image of Ag/kaolin is shown in Figure 4. The image has shown the particle size of $50 \mathrm{~nm}$. Figure 4 has shown the small black points on the picture. This is due to a large amount of Ag nanoparticles on the surface of kaolin. It is detected that $\mathrm{Ag}$ nanoparticles are distributed over the surface of kaolin in the form of massive agglomeration.

The $\mathrm{N}_{2}$ adsorption-desorption isotherms of kaolin and $\mathrm{Ag} /$ kaolin nanocomposite are presented in Figure 5. The isotherms are between type IV and II, which is the characteristic of porous structures. The hysteresis loop, which is very common in this type of clays [32], is associated with network effects of $\mathrm{N}_{2}$ desorption from the house of cards structure, indicating the random orientation of layers. Physical properties of kaolin and $\mathrm{Ag} / \mathrm{kaolin}$ are listed in Table 1.

As expected, the BET surface area, total pore volume, and a mesopore size are increased from kaolin to $\mathrm{Ag} / \mathrm{kaolin}$. Increasing surface area from $1.0215 \mathrm{~m}^{2} \mathrm{~g}^{-1}$ to $7.409 \mathrm{~m}^{2} \mathrm{~g}^{-1}$

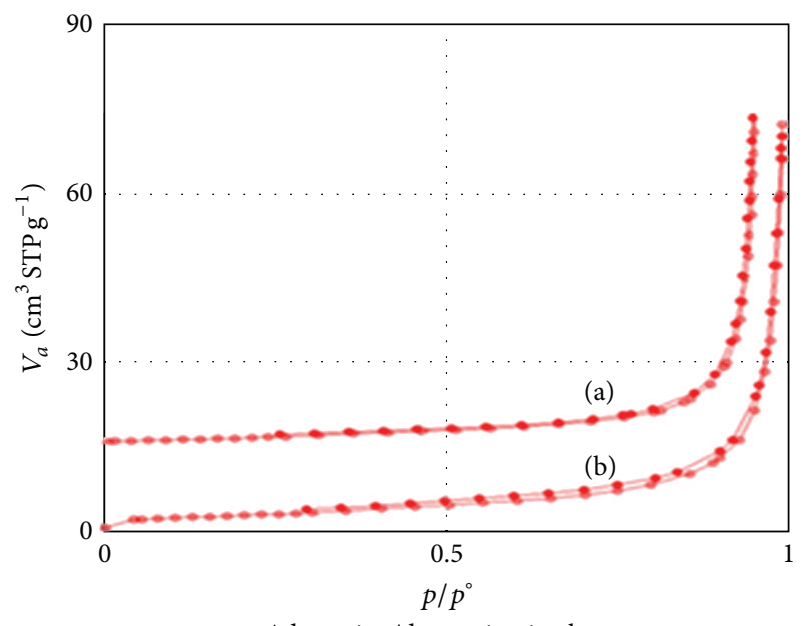

Adsorption/desorption isotherm

FIGURE 5: Nitrogen adsorption/desorption isotherm of (a) kaolin and (b) Ag/kaolin.

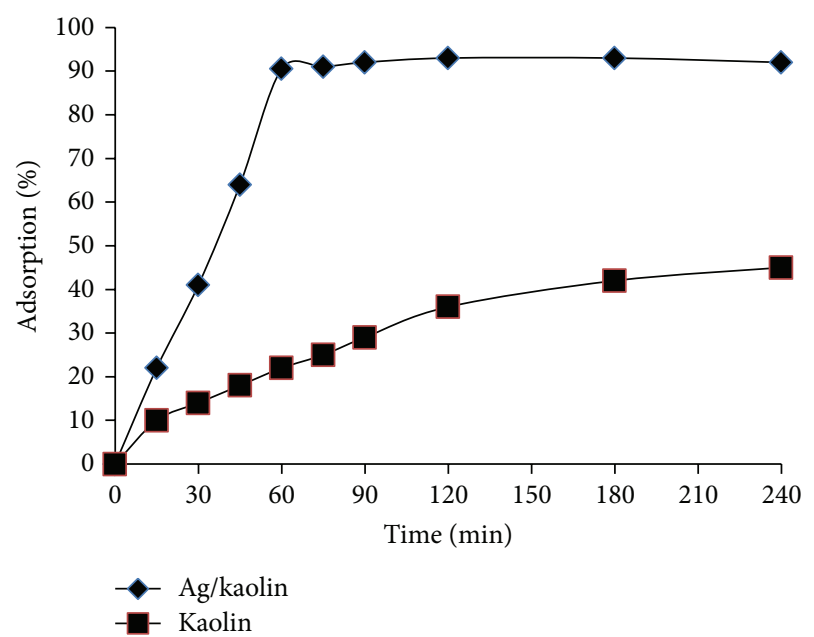

FIGURE 6: Effect of contact time on the adsorption of AC5R on (a) kaolin (b) Ag/kaolin (30 mL AC5R solution, initial concentration $40 \mathrm{mg} \mathrm{L}^{-1}, 0.1 \mathrm{~g}$ adsorbent).

from kaolin to $\mathrm{Ag} / \mathrm{kaolin}$ confirmed the formation of new porous structures.

\subsection{Adsorption Study}

3.2.1. Effect of Contact Time. Effect of contact time on the adsorption of $\mathrm{AC5R}$ onto $\mathrm{Ag} / \mathrm{kaolin}$ nanocomposite was investigated. It can be observed from Figure 6 that the dye adsorption increases with the increasing of treating time. The adsorption of samples attained about $45 \%$ after $240 \mathrm{~min}$ of contact time for kaolin and $90 \%$ at 60 min of contact time for $\mathrm{Ag} / \mathrm{kaolin}$. As could be seen from Figure 6, the adsorption efficiency of AC5R onto $\mathrm{Ag} / \mathrm{kaolin}$ nanocomposite occurs rapidly in the first $60 \mathrm{~min}$, after that the adsorption of dye is slowly until the equilibrium is obtained [8]. The high percentage removal of AC5R by Ag/kaolin can be attributed to catalytic activity of $\mathrm{Ag}$ on the surface of kaolin [27]. 


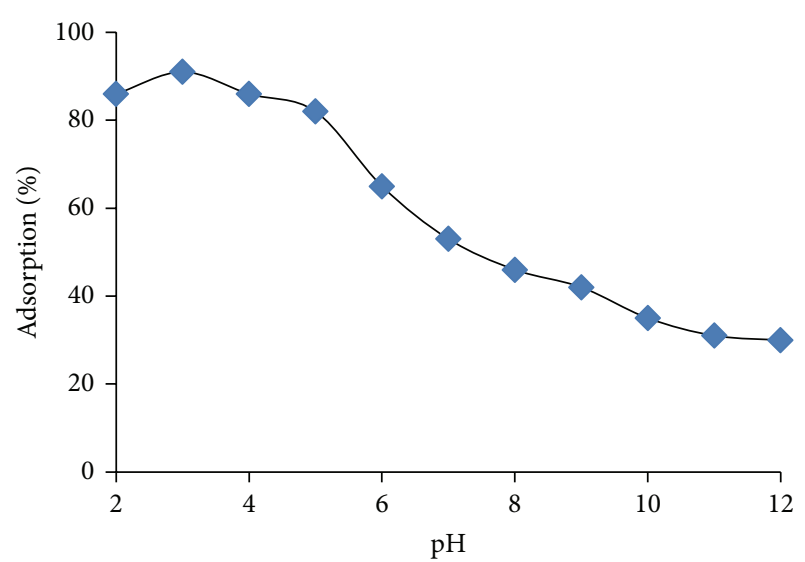

FIGURE 7: Effect of solution $\mathrm{pH}$ on the adsorption of AC5R onto $\mathrm{Ag} / \mathrm{kaolin}$ (nanocomposite $30 \mathrm{~mL}$ AC5R solution, initial concentration $40 \mathrm{mg} \mathrm{L}^{-1}, 0.1 \mathrm{~g}$ adsorbent).

The FTIR spectra of $\mathrm{Ag} / \mathrm{kaolin}$ nanocomposite before and after adsorption of AC5R have also shown the presence of AC5R onto the $\mathrm{Ag} / \mathrm{kaolin}$ (no Fig).

3.2.2. Effect of $p H$. The $\mathrm{pH}$ of the system is very important parameter on the adsorption process. Figure 7 shows the effect of $\mathrm{pH}$ on the adsorption of AC5R onto $\mathrm{Ag} / \mathrm{kaolin}$ nano composite. The adsorption capacity decreases with increasing $\mathrm{pH}$ of the solution. The maximum adsorption of AC5R on $\mathrm{Ag} / \mathrm{kaolin}$ nanocomposite is found at $\mathrm{pH}$. This could be explained by the fact that at low $\mathrm{pH}$, more protons will be available to protonate amine and hydroxyl groups. It causes increasing the number of binding sites for the adsorption of AC5R. The influence of $\mathrm{pH}$ on the adsorption capacity showed decreasing affinity with increasing electrostatic repulsion between $\mathrm{AC} 5 \mathrm{R}$ and $\mathrm{Ag} / \mathrm{kaolin}$ nanocomposite. At high $\mathrm{pH}$ value the repulsion between AC5R and adsorbent was done [8].

3.2.3. Effect of Amount of Sorbent. The effect of mass of $\mathrm{Ag} / \mathrm{kaolin}$ nanocomposite on the sorption for $30 \mathrm{~mL}$ of AC5R $40 \mathrm{mg} \mathrm{L}^{-1}$ is shown in Figure 8. The AC5R removal increases rapidly with increasing in mass of $\mathrm{Ag} / \mathrm{kaolin}$ nanocomposite up to $0.5 \mathrm{~g}$. An increase in the adsorption with adsorbent dosage can be attributed to the availability for more adsorption sites and greater surface area for contact. The removal between 0.5 and $2 \mathrm{~g}$ of sorbent dosage is only marginal. At $\mathrm{Ag} / \mathrm{kaolin}$ nanocomposite more than $0.50 \mathrm{~g}$, the incremental AC5R removal is very small $[33,34]$.

3.3. Kinetic of Adsorption. The kinetic study of the adsorption process provides useful data regarding the efficiency of adsorption and feasibility of scale-up operations. The adsorption kinetic experiments were carried out to evaluate the rate of a sorption process on the $\mathrm{Ag} / \mathrm{kaolin}$ nanocomposite. The kinetic data of adsorption can be evaluated using different types of mathematical models.

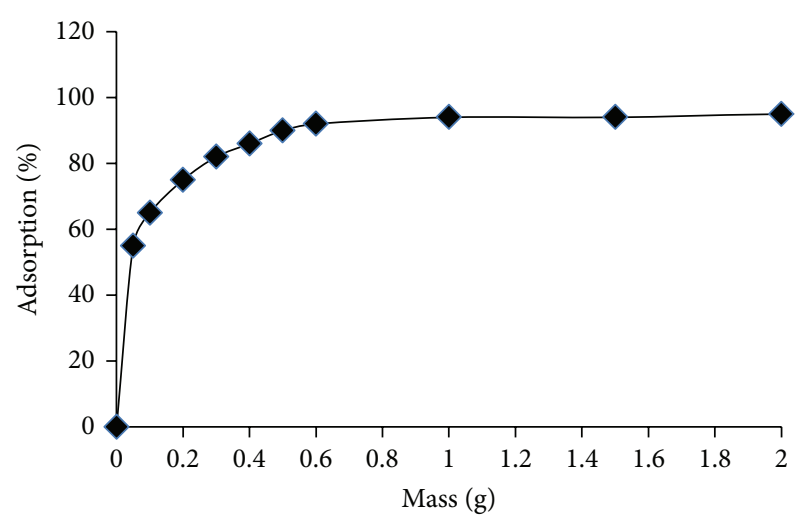

FIGURE 8: Effect of amount of Ag/kaolin composite on the sorption of AC5R (30 mL of AC5R solution, initial concentrations $40 \mathrm{mg} \mathrm{L}^{-1}$, initial $\mathrm{pH} 3.0$, and contact time $60 \mathrm{~min}$ ).

The transient behavior of AC5R adsorption process was analyzed by using the pseudo-first order and pseudo-secondorder kinetic models [34-37]. The pseudo-first order model assumes that the rate of change of solute uptake with time is directly proportional to difference in saturation concentration and amount of solid uptake with time:

$$
\ln \left(q_{e}-q_{t}\right)=\ln q_{e}-k_{1} t
$$

where $q_{e}$ and $q_{t}$ are the amounts of AC5R adsorbed per united mass of the adsorbent $\left(\mathrm{mgg}^{-1}\right)$ at equilibrium and time $t$, respectively, and $k_{1}$ is the rate constant of adsorption $\left(\mathrm{min}^{-1}\right)$. When $\ln \left(q_{e}-q_{t}\right)$ was plotted against time, a straight line should be obtained with a slope of $k_{1}$ if the first order kinetics is valid.

The pseudo-second order model has the following form:

$$
\frac{t}{q_{t}}=\frac{t}{q_{e}}+\frac{1}{k_{2} q_{e}^{2}}
$$

where $q_{e}$ and $q_{t}$ represent the amount of AC5R adsorbed $\left(\mathrm{mg} \mathrm{g}^{-1}\right)$ at equilibrium and at any time and $k_{2}$ in the rate constant of the pseudo-second order equation $\left(\mathrm{g} \mathrm{mg}^{-1} \mathrm{~min}^{-1}\right)$. A plot of $t / q$ versus time $(t)$ would yield a line with a slope of $1 / q_{e}$ and an intercept of $1 /\left(k_{2} q_{e}^{2}\right)$ if the second order model is a suitable expression. The kinetic model with a higher correlation coefficient $R^{2}$ was selected as the most suitable one (Figures 9(a) and 9(b)). It was found that application of pseudo-second-order kinetic model to (3) provides better correlation coefficient of experimental data.

3.4. Adsorption Isotherm of AC5R. Adsorption isotherm is important to describe how solutes interact with adsorbent. The Langmuir and Freundlich equations were employed to study the sorption isotherms of AC5R. The Langmuir adsorption model is given as

$$
\frac{1}{q_{e}}=\frac{1}{q_{m}}+\frac{1}{K_{L} q_{m} C_{e}}
$$

where $q_{e}$ is the adsorbed amount at the equilibrium $\left(\mathrm{mg} \mathrm{g}^{-1}\right)$, $q_{m}$ is the maximum adsorbed amount $\left(\mathrm{mgg}^{-1}\right), C_{e}$ is 


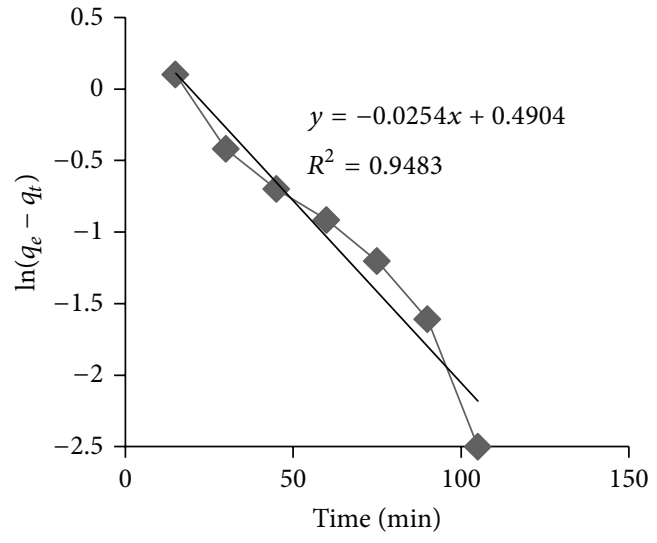

(a)

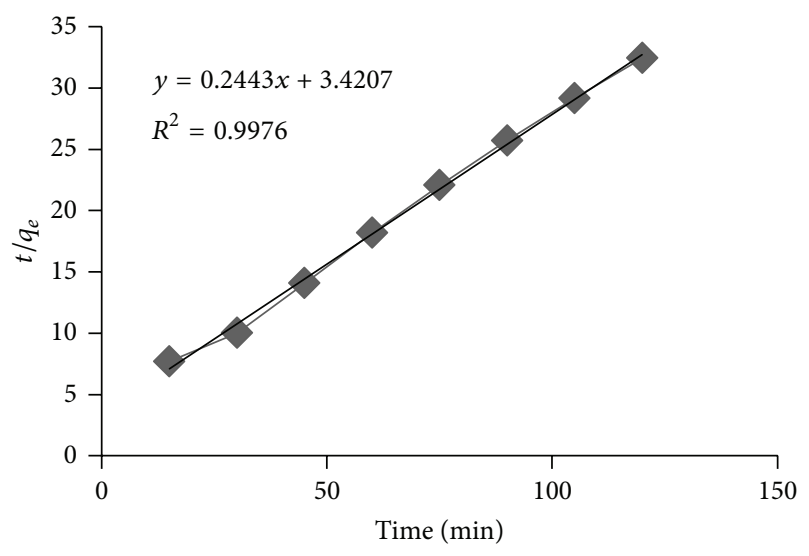

(b)

FIGURE 9: (a) pseudo-first-order and (b) pseudo-second-order kinetic for adsorption of AC5R onto Ag/kaolin nanocomposite (30 mL AC5R solution, initial concentration $40 \mathrm{mg} \mathrm{L}^{-1}$, initial $\mathrm{pH} 3.0$, and $0.5 \mathrm{~g}$ adsorbent).

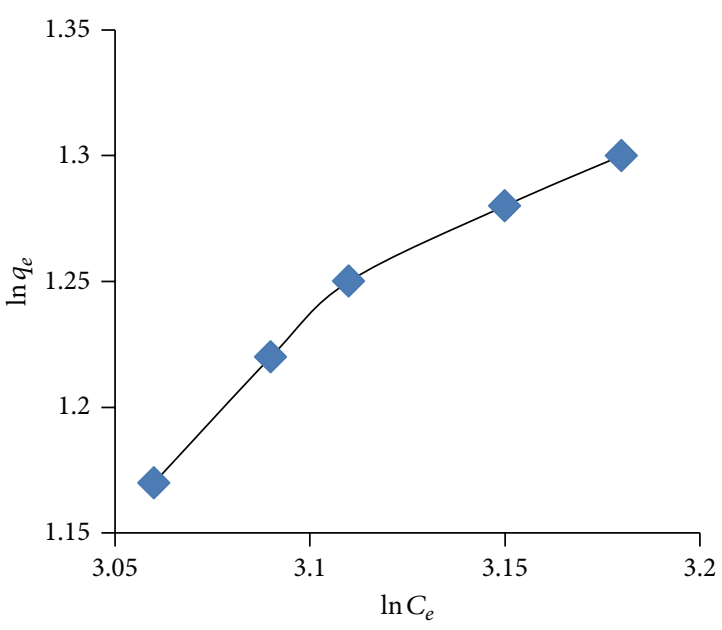

(a)

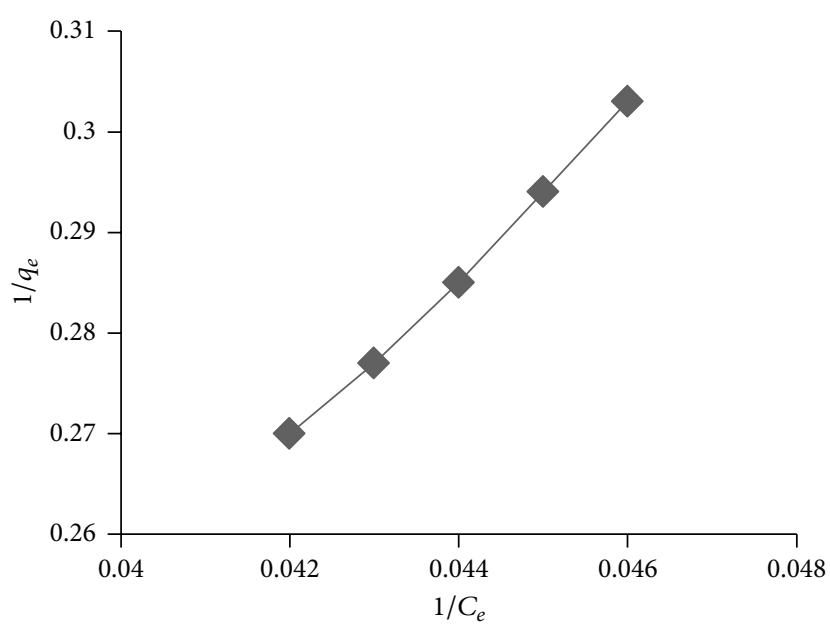

(b)

Figure 10: (a) Freundlich and (b) Langmuir plot for AC5R sorption onto Ag/kaolin (30 mL AC5R solution, initial concentration $40 \mathrm{mg} \mathrm{L}{ }^{-1}$, and initial $\mathrm{pH}$ 3.0, $0.1 \mathrm{~g}$ adsorbent).

the equilibrium concentration of AC5R dye in the solution ( $\mathrm{mg} \mathrm{L}^{-1}$ ), and $K_{L}$ is the Langmuir constant related to the affinity of binding sites $\left(\mathrm{mL} \mathrm{mg}^{-1}\right)$.

Freundlich adsorption isotherm model, which is an empirical equation used to describe heterogenous adsorption system, can be represented as follows:

$$
\log q_{e}=\log K_{F}+\frac{1}{n \log C_{e}},
$$

where $q_{e}$ is defined as above, $K_{F}$ is Freundlich constant representing the adsorption capacity $\left(\mathrm{mg} \mathrm{g}^{-1}\right)$, and $n$ is the heterogeneity factor depicting the adsorption intensity.

Figures 10(a) and 10(b) show the adsorption isotherms of Freundlich and Langmuir. The regression equations and parameters $K_{F}, K_{L}$, and $n$, as well as the correlation coefficients $R^{2}$ are summarized in Table 2. As known to us, Langmuir isotherm is on the supposition that the surface of
TABLE 2: Langmuir and Freundlich constants for the adsorption of AC5R onto Ag/kaolin nanocomposite.

\begin{tabular}{lcccccc}
\hline \multirow{2}{*}{ Adsorbent } & \multicolumn{3}{c}{ Freundlich } & \multicolumn{3}{c}{ Langmuir } \\
& $R^{2}$ & $K_{F}$ & $1 / n$ & $R^{2}$ & $K_{L}$ & $Q_{m}\left(\mathrm{mg} \mathrm{g}^{-1}\right)$ \\
\hline Ag/kaolin & 0.993 & 0.981 & 0.23 & 0.997 & 0.0095 & 12.65 \\
Kaolin & 0.994 & 0.851 & 0.205 & 0.995 & 0.089 & 9.45 \\
\hline
\end{tabular}

the adsorbent is a homogenous surface, whereas Freundlich isotherm is applied to the adsorption process on the heterogeneous surface. It is evident from Table 2 the equilibrium data were better represented by Langmuir isotherm equation than done by the Freundlich equation $[28,29,38]$.

3.5. Thermodynamic Parameters. Thermodynamic parameters such as standard-free energy $\left(\Delta G^{\circ}\right)$, enthalpy $\left(\Delta H^{\circ}\right)$, and 
TABLE 3: Thermodynamic parameters of AC5R adsorption onto $\mathrm{Ag} / \mathrm{kaolin}$ nano composite.

\begin{tabular}{lccc}
\hline$\Delta S^{\circ}\left(\mathrm{J} \mathrm{mol}^{-1} \mathrm{k}^{-1}\right)$ & $\Delta H^{\circ}\left(\mathrm{J} \mathrm{mol}^{-1}\right)$ & $\Delta G^{\circ}\left(\mathrm{KJ} \mathrm{mol}^{-1}\right)$ & $T(\mathrm{~K})$ \\
\hline & & -6.398 & 298 \\
& & -8.769 & 303 \\
& & -10.47 & 308 \\
& 24.77 & -10.778 & 313 \\
& & -11.26 & 318 \\
& & -11.87 & 333 \\
\hline
\end{tabular}

entropy $\left(\Delta S^{\circ}\right)$ are the actual indicators for practical application of adsorption process. The thermodynamic parameters for adsorption process of AC5R onto $\mathrm{Ag} / \mathrm{kaolin}$ were determined at different temperatures using the following equations [37]:

$$
\Delta G^{\circ}=-R T \ln K_{C}
$$

where $\Delta G^{\circ}$ is the standard-free energy change, $T$ is the absolute temperature, $R$ is the universal gas constant $\left(8.314 \mathrm{~J} \cdot \mathrm{mol}^{-1} \mathrm{~K}^{-1}\right.$ ) and $K_{\mathrm{C}}$ is the equilibrium constant. The apparent equilibrium constant of the sorption, $K_{C}$, is obtained from

$$
K_{C}=\frac{C_{A}}{C_{S}},
$$

where $K_{C}$ is the equilibrium constant, $C_{A}$ is the amount of AC5R adsorbed on the adsorbent of solution at equilibrium $\left(\mathrm{mg} \mathrm{g}^{-1}\right), C_{S}$ is the equilibrium concentration of AC5R in the solution $\left(\mathrm{mg} \mathrm{L}^{-1}\right) . K_{\mathrm{C}}$ values and calculated at different temperatures to allow the determination of the thermodynamic equilibrium constant $\left(K_{C}\right)[39,40]$. The free energy changes are also calculated by using the following equations:

$$
\ln K_{C}=-\frac{\Delta G^{\circ}}{R T}=-\frac{\Delta H^{\circ}}{R T}+\frac{\Delta S^{\circ}}{R},
$$

where $\Delta H^{\circ}$ and $\Delta S^{\circ}$ were as calculated the slope and intercept of van't Hoff plots of $\ln K_{C}$ versus $1 / T$. The results of thermodynamic parameters of $\mathrm{AC} 5 \mathrm{R}$ adsorption onto $\mathrm{Ag} / \mathrm{kaolin}$ are given in Table 3.

\section{Conclusion}

$\mathrm{Ag} / \mathrm{kaolin}$ nanocomposite with average size $\sim 50 \mathrm{~nm}$ has been synthesized. It was used for the removal of acid cyanine $5 \mathrm{R}$ dye (AC5R) from water. The particles were characterized using FTIR, XRD, and TEM. The adsorption process could be described by the second-order kinetic model. The Langmuir isotherm is suitable for characterization experimental adsorption isotherm. The process of purifying water pollution presented here is clean and safe. Hence, it provides a simple and environment friendly separation tool for the removal of organic dyes or other pollutants.

\section{References}

[1] T. Sauer, G. Cesconeto Neto, H. J. José, and R. F. P. M. Moreira, "Kinetics of photocatalytic degradation of reactive dyes in a
$\mathrm{TiO}_{2}$ slurry reactor," Journal of Photochemistry and Photobiology A, vol. 149, no. 1-3, pp. 147-154, 2002.

[2] J. Chen and L. Zhu, "Catalytic degradation of Orange II by UV-Fenton with hydroxyl-Fe-pillared bentonite in water," Chemosphere, vol. 65, no. 7, pp. 1249-1255, 2006.

[3] K. Y. Foo and B. H. Hameed, "Microwave-assisted preparation of oil palm fiber activated carbon for methylene blue adsorption," Chemical Engineering Journal, vol. 166, no. 2, pp. 792-795, 2011.

[4] E. Guibal and J. Roussy, "Coagulation and flocculation of dyecontaining solutions using a biopolymer (Chitosan)," Reactive and Functional Polymers, vol. 67, no. 1, pp. 33-42, 2007.

[5] V. K. Gupta, R. Jain, and S. Varshney, "Electrochemical removal of the hazardous dye Reactofix Red 3 BFN from industrial effluents," Journal of Colloid and Interface Science, vol. 312, no. 2, pp. 292-296, 2007.

[6] L. Gomes, D. W. Miwa, G. R. P. Malpass, and A. J. Motheo, "Electrochemical degradation of the dye reactive orange 16 using electrochemical flow-cell," Journal of the Brazilian Chemical Society, vol. 22, no. 7, pp. 1299-1306, 2011.

[7] G. Crini, "Non-conventional low-cost adsorbents for dye removal: a review," Bioresource Technology, vol. 97, no. 9, pp. 1061-1085, 2006.

[8] S. Hashemian and M. Salimi, "Nano composite a potential low cost adsorbent for removal of cyanine acid," Chemical Engineering Journal, vol. 188, pp. 57-63, 2012.

[9] M. Doǧan, M. Alkan, A. Türkyilmaz, and Y. Özdemir, "Kinetics and mechanism of removal of methylene blue by adsorption onto perlite," Journal of Hazardous Materials, vol. 109, no. 1-3, pp. 141-148, 2004.

[10] M. T. Uddin, M. A. Islam, S. Mahmud, and M. Rukanuzzaman, "Adsorptive removal of methylene blue by tea waste," Journal of Hazardous Materials, vol. 164, no. 1, pp. 53-60, 2009.

[11] A. Shukla, Y.-H. Zhang, P. Dubey, J. L. Margrave, and S. S. Shukla, "The role of sawdust in the removal of unwanted materials from water," Journal of Hazardous Materials, vol. 95, no. 1-2, pp. 137-152, 2002.

[12] N. Nasuha and B. H. Hameed, "Adsorption of methylene blue from aqueous solution onto $\mathrm{NaOH}$-modified rejected tea," Chemical Engineering Journal, vol. 166, no. 2, pp. 783-786, 2011.

[13] S. Hashemian and M. Monshizadeh, "Removal of methylene blue from aqueous solution by nano $\mathrm{LaFeO}_{3}$ particles," Main Group Chemistry, vol. 12, no. 2, pp. 113-124, 2013.

[14] S. Hashemian, K. Salari, and Z. Atashi, "Preparation of activated carbon from agricultural wastes (almond shell and orange peel) for adsorption of 2-pic from aqueous solution," Journal of Industrial and Engineering Chemistry, 2013.

[15] H. A. Patel, H. C. Bajaj, and R. V. Jasra, "Sorption of nitrobenzene from aqueous solution on organoclays in batch and fixedbed systems," Industrial and Engineering Chemistry Research, vol. 48, no. 2, pp. 1051-1058, 2009.

[16] G. B. Behera, P. K. Behera, and B. K. Mishra, "Cyanine dyes: self aggregation and behaviour in surfactants: a review," Journal of Surface Science and Technology, vol. 23, no. 1-2, pp. 1-31, 2007.

[17] A. Mishra, R. K. Behera, P. K. Behera, B. K. Mishra, and G. B. Behera, "Cyanines during the 1990s: a review," Chemical Reviews, vol. 100, no. 6, pp. 1973-2011, 2000.

[18] P. S. Nayak and B. K. Singh, "Instrumental characterization of clay by XRF, XRD and FTIR," Bulletin of Materials Science, vol. 30, no. 3, pp. 235-238, 2007. 
[19] M. Hamdi Karaoǧlu, M. Doǧan, and M. Alkan, "Kinetic analysis of reactive blue 221 adsorption on kaolinite," Desalination, vol. 256, no. 1-3, pp. 154-165, 2010.

[20] A. Safa Özcan, B. Erdem, and A. Özcan, "Adsorption of acid blue 193 from aqueous solutions onto Na-bentonite and DTMAbentonite," Journal of Colloid and Interface Science, vol. 280, no. 1, pp. 44-54, 2004.

[21] S. Hashemian, "Study of adsorption of acid dye from aqueous solutions using bentonite," Main Group Chemistry, vol. 6, no. 2, pp. 97-107, 2007.

[22] S. Hashemian, " $\mathrm{MnFe}_{2} \mathrm{O}_{4}$ /bentonite nano composite as a novel magnetic material for adsorption of acid red 138," African Journal of Biotechnology, vol. 9, no. 50, pp. 8667-8671, 2010.

[23] S. Hashemian, "Removal of acid red 151 from water by adsorption onto nano-composite $\mathrm{MnFe}_{2} \mathrm{O}_{4}$ /kaolin," Main Group Chemistry, vol. 10, no. 2, pp. 105-114, 2011.

[24] H. A. Patel, R. S. Somani, H. C. Bajaj, and R. V. Jasra, "Nanoclays for polymer nanocomposites, paints, inks, greases and cosmetics formulations, drug delivery vehicle and waste water treatment," Bulletin of Materials Science, vol. 29, no. 2, pp. 133-145, 2006.

[25] S. H. Sonawane, P. L. Chaudhari, S. A. Ghodke et al., "Ultrasound assisted synthesis of polyacrylic acid-nanoclay nanocomposite and its application in sonosorption studies of malachite green dye," Ultrasonics Sonochemistry, vol. 16, no. 3, pp. 351-355, 2009.

[26] K.-T. Lau, C. Gu, and D. Hui, "A critical review on nanotube and nanotube/nanoclay related polymer composite materials," Composites B, vol. 37, no. 6, pp. 425-436, 2006.

[27] W. Li, C. Sun, B. Hou, and X. Zhou, "Room temperature synthesis and catalytic properties of surfactant-modified Ag nanoparticles," International Journal of Spectroscopy, vol. 2012, Article ID 638692, 7 pages, 2012.

[28] S. Razi Seyedmonir, D. E. Strohmayer, G. L. Geoffroy, M. Albert Vannice, H. W. Young, and J. W. Linowski, "Characterization ofsupported silver catalysts. I. Adsorption of $\mathrm{O}_{2}, \mathrm{H}_{2}, \mathrm{~N}_{2} \mathrm{O}$, and the $\mathrm{H}_{2}$-titration of adsorbed oxygen on well-dispersed $\mathrm{Ag}$ on $\mathrm{TiO}_{2}$," Journal of Catalysis, vol. 87, no. 2, pp. 424-436, 1984.

[29] Y. S. Ho and G. McKay, "Pseudo-second order model for sorption process," Chemical Engineering Journal, vol. 70, pp. 115-124, 1998.

[30] B. P. Matselyukh, D. Ya. Matselyukh, V. B. Kovalska1, K. D. Volkoval, D. V. Kryvorotenko, and S. M. Yarmoluk, "Studies of mutagenic activity of fluorescent DNA sensitive monomethinecyanine and carbocyanine dyes in Ames test," Ukrainica Bioorganica Acta, vol. 2, pp. 27-34, 2005.

[31] X. Jiang, S. Chen, and C. Mao, "Synthesis of $\mathrm{Ag} / \mathrm{SiO}_{2}$ nanocomposite material by adsorption phase nanoreactor technique," Colloids and Surfaces A, vol. 320, no. 1-3, pp. 104-110, 2008.

[32] F. Li, Y. Jiang, M. Xia, M. Sun, B. Xue, and X. Ren, "A novel mesoporous silica-clay composite and its thermal and hydrothermal stabilities," Journal of Porous Materials, vol. 17, no. 2, pp. 217-223, 2010.

[33] D. H. Lataye, I. M. Mishra, and I. D. Mall, "Removal of pyridine from aqueous solution by adsorption on bagasse fly ash," Industrial and Engineering Chemistry Research, vol. 45, no. 11, pp. 3934-3943, 2006.

[34] D. H. Lataye, I. M. Mishra, and I. D. Mall, "Adsorption of 2picoline onto bagasse fly ash from aqueous solution," Chemical Engineering Journal, vol. 138, no. 1-3, pp. 35-46, 2008.
[35] S. Lagergren, "Zur theorie der sogenannten adsorption geloster stoffe Kungliga Svenska Vetenskapsakademiens," Handlingar, vol. 24, pp. 1-39, 1898.

[36] Y. S. Ho, G. McKay, D. A. J. Wase, and C. F. Foster, "Study of the sorption of divalentmetal ions on to peat," Adsorption Science and Technology, vol. 18, no. 7, pp. 639-650, 2000.

[37] Y. Bulut and H. Aydin, "A kinetics and thermodynamics study of methylene blue adsorption on wheat shells," Desalination, vol. 194, no. 1-3, pp. 259-267, 2006.

[38] M. E. Argun, S. Dursun, C. Ozdemir, and M. Karatas, "Heavy metal adsorption by modified oak sawdust: thermodynamics and kinetics," Journal of Hazardous Materials, vol. 141, no. 1, pp. 77-85, 2007.

[39] B. H. Hameed, A. A. Ahmad, and N. Aziz, "Isotherms, kinetics and thermodynamics of acid dye adsorption on activated palm ash," Chemical Engineering Journal, vol. 133, no. 1-3, pp. 195-203, 2007.

[40] S. Hashemian and M. Mirshamsi, "Kinetic and thermodynamic of adsorption of 2-picoline by sawdust from aqueous solution," Journal of Industrial and Engineering Chemistry, vol. 18, no. 6, pp. 2010-2015, 2012. 

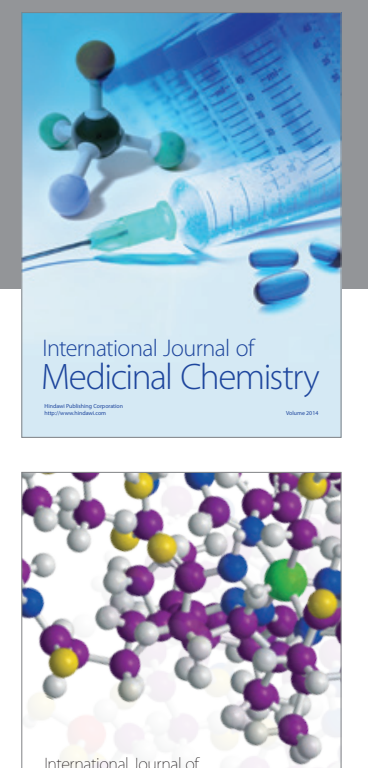

\section{Carbohydrate} Chemistry

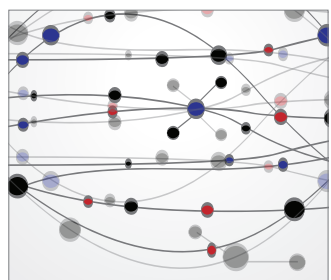

The Scientific World Journal
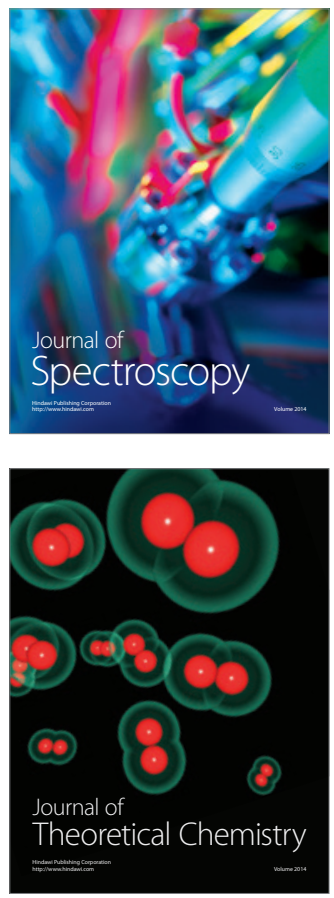
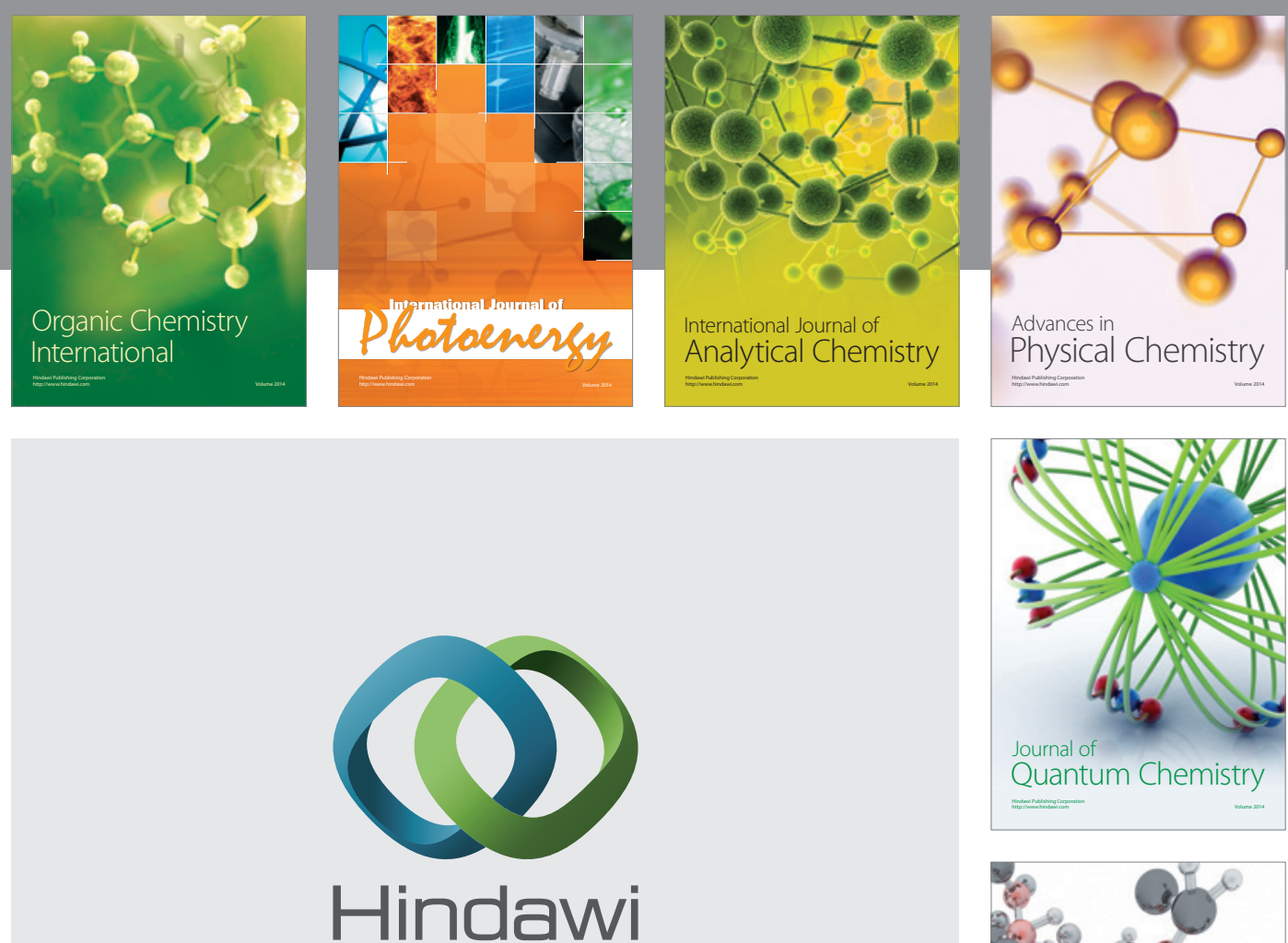

Submit your manuscripts at

http://www.hindawi.com

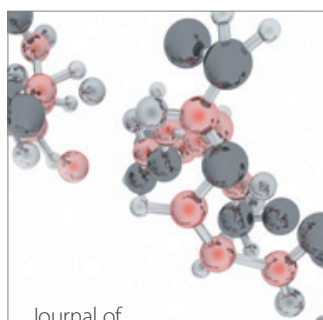

Analytical Methods

in Chemistry

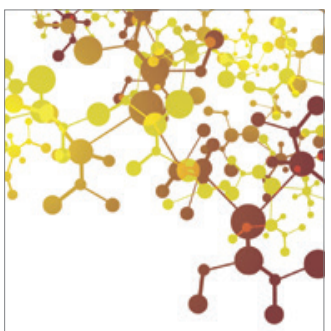

Journal of

Applied Chemistry

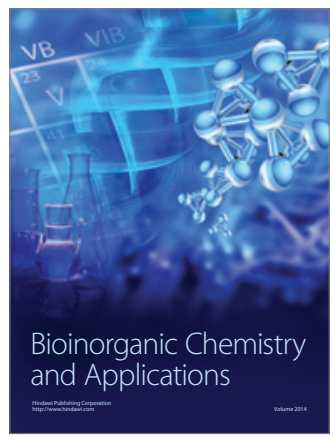

Inorganic Chemistry
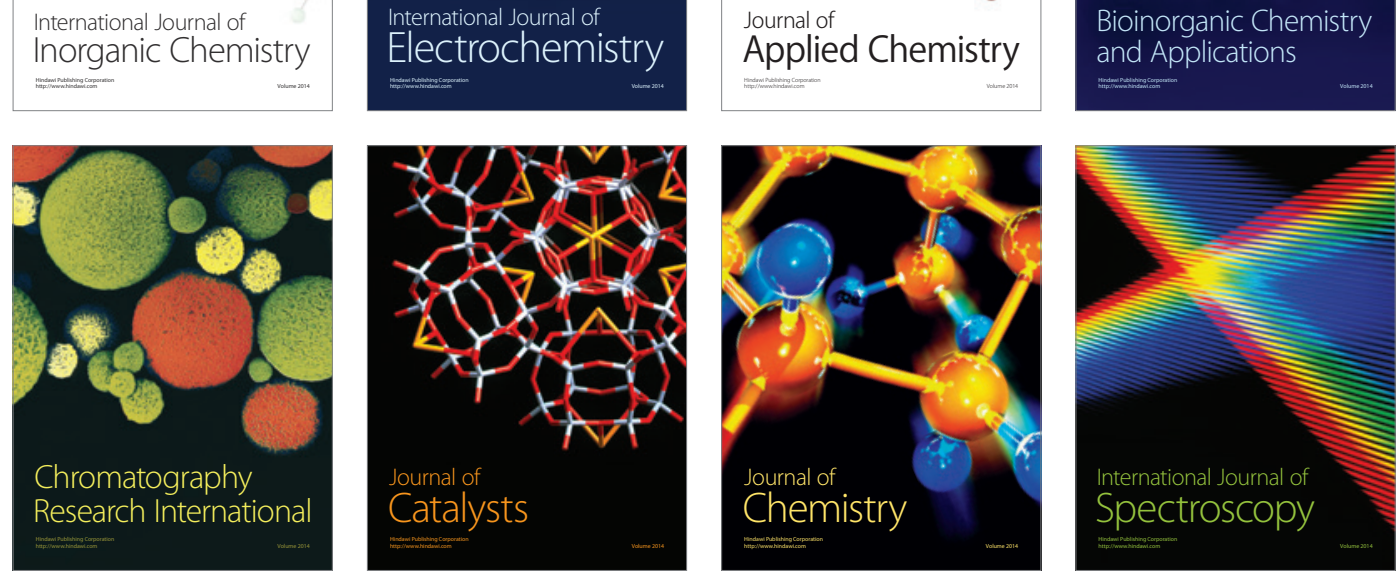